the ice sheet into two parts, one in the Builth Wells lowlands and one in the Usk valley. Consequently the ice to the south became dead and melted in situ, as in the Llynfi basin. The Wye, however, is aligned north/south for some 10 miles below Builth Wells so that, as the ice sheet decayed, a valley glacier was still able to exist in it. The terminal moraines in this section of the valley testify to the existence of the glacier.

Although the southern limit of this ice sheet has been traced, little is known about its other borders. Watson ${ }^{9-11}$ has shown that the area between the east/west watershed of Wales, south of the Dyfi/Severn line, and around Cardigan Bay, was free of ice during the last glaciation and that periglacial (solifluction) terraces exist in the Wye valley above Llangurig ${ }^{12}$. Pissart ${ }^{13}$ also described pingos near Llangurig, developed on outwash material. This suggests that the ice sheet lay east and south of Llangurig, probably on the semi-circle of high ground around Rhayador. The western limit of the ice may be represented by the Tregaron moraine, and it is unlikely to have spread north to the Severn.

I believe that a local Mid-Wales ice-cap existed during the Last Glaciation and that much of it melted in situ, the southern limit of the ice cap being the Breconshireend moraine.

I thank Mr. E. Watson and Mr. F. Synge for their advice and encouragement.

Department of Geography, University College, Dublin.

Received November 7, revised November 16, 1966.

' Charlesworth, J. K., Quart. J. Geol. Soc., 85, 335 (1929).

2Mitchell, G. F., Adv. Sci., 17, 313 (1960).

${ }^{3}$ Bowen, D. Q., Nature, 211, 475 (1966).

+ Geol. Survey Sheet 231, 1: 63, 360 .

Lewis, C. A., thesis, Nat. Univ. Ireland (1966).

- Pocock, Rev. T. I., Zeit. für Gletscherkunde, 14, 10 (1925)

${ }^{7}$ Grindley. Rev. H. E.. Trans. Woolhope Nat. Field Club, 163 (1905).

* Pocock, Rev. T. I., Zeit. für Gletscherkunde, 27, 98 (1940).

"Watson, E., Bull. Assoc. Geog. Français, 338/8, 16 (1965).

10 Watson, E., Proc. Geol. Assoc., 76, 443 (1965).

"Watson, F., Buil. Peryglacjalny, 15, 79 (1966).

12 Watson, E., Welsh Soils Discussion Group, 2, 11 (1961).

is Pissart, A., Zeit. für. Geomorph., 7, 147 (1963).

\section{Clara-Knockrath Unconformity in South-east Ireland}

DURINe a recent re-examination of the Trooperstown Hill area, about $2 \cdot 25$ miles N.N.W. of Rathdrum in Co. Wicklow, I found an exposure of the unconformity between the Clara Series and Knockrath Series which had been postulated on structural grounds ${ }^{1}$.

The unconformity is exposed in the stream which flows down the northern flanks of Trooporstown Hill, some 460 yd. S.S.W. of Trooperstown Bridge, where in figure 2 of ref. I the Knockrath strata are shown striking N.W. and vertical, that is, about $10 \mathrm{yd}$. west of the position previously postulated. About a foot away from this vertical occurrence the attitude of the Knockrath siltstones and slates changes to a sub-horizontal one, and a few inches of Clara mudstones can be seen resting on top of them. It is unfortunate, therefore, that by chance in this small exposure the angular discordance is generally small, while a short distance away it might easily have been close to $90^{\circ}$. Nevertheloss the strong deformation of the rocks under the unconformity is clearly visible and polished and thin sections show slight angular discordance in most places, while Iarge angular discordances are shown locally. Tho base of the Clara Series is marked by a very fine-grained band of chort, noarly colourloss in thin. section and often finely laminated, with an average thicknoss of $0.5 \mathrm{~mm}$. Above this comes an iron-rich layer (mostly magnetite with some limonite), generally about $0.5-1.5 \mathrm{~mm}$ in thickness. A few similar layers, less con- tinuously developed, may also oceur in this basal position of the mudstones, but are absent at exposures more than a few yards from the unconformity. There is evidence of some redistribution of this iron in the basal Clara rocks, while there is also abundant iron staining and impregnation in the rocks immodiately under the unconformity (gencrally to a depth of about 5-10 mm).

The discovery of this exposure is important in confirming the unconformity previously postulated between the Clara and Knockrath Series. It is fortunate that in the Trooperstown area the basal Clara rocks and the underlying Knockrath Sories have completely escaped the Calodonian deformation, which was fairly severe in most of southeastern Ireland. It is, however, a reflexion of the common rigidity of the underlying previously deformed Pre-Cambrian rocks, which havo often resisted further folding during the Caledonian orogeny, deformation being confined largely to movement along faults and shearzones. In the Trooperstown area a fracture-cleavage develops in the Clara rocks within 200-400 yd. of the outerop of their base, and this passes quickly into a true cleavage.

Tho Clara Series most probably represents some part of the Cambrian System in southeastern Ireland, as it was apparently deposited unconformably on both Knockrath and Bray strata after they had suffered strong orogenic deformation and prolonged erosion. It is also succeoded conformably by the Dunganstown Sandstones, which, on the basis of lithological comparison and thicknesses of strata in the two limbs of the Leinster synclinorium, are almost certainly of Arenig age (ef. the Ribband Series of Harper ${ }^{2}$ ). Small brachiopods found in Clara rocks in 1959 were inconclusive for dating ${ }^{1}$, but it is hoped that current micropalaeontological investigations may prove more helpful on this point.

\section{W. E. TremletT}

Department of Geology,

University of Glasgow.

1 Tremlett, W. E.. Geol. Mag., 96, 58 (1959)

- Harper, J. C.. Proc. Liverpool Geol. Soc., 20, 48 (1948).

\section{High-absorbing Layer in the Terrestrial Atmosphere}

Ney and Popin ${ }^{1}$ inferred from the photometry of a stellar photograph from Gemini 9 that "either Link's layer does not exist at all or it is at lower altitude than $80 \mathrm{~km}$ ". I should like, therefore, to point out that I arrived at the second alternative of their conclusion as early as the year 1948, on the basis of a comparison of extinction and twilight phenomona ${ }^{2}$. This conclusion is also to be found in my review work ${ }^{3}$.

It is, however, necessary to admit that the observations made by the astronauts have brought some confusion into the matter. The luminous layer as observed in the high atmosphere by Glenn and his successors has been successively explained as a parasite reflexion on the wedge windows of the cabin, as an airglow emission at $5577 \AA$, and, when its intensity was found to differ from the known value, as an airglow continuum, and ultimately as the diffusion of the moonlight in the high absorbing layer, the first mention of which is to be found as early as the year 1895 by Hausdorff. Feoktistov ${ }^{5}$, the first scientist in space, observed that the high layer illuminated by the Moon appeared to be brightest below the Moon and that its intensity decreased with the angular distanee from the Moon, which seems to prove that there is a diffusion component in the light of the layer.

The photometric results of Ney and Pepin are not quite convincing. Photomotry of a distorted stellar image projected on the bright background of the layer (illuminated by the Moon) is as delicate a matter as the use of a 